\title{
PENGGUNAAN TEKNIK MENULIS SEMI TERPIMPIN UNTUK MENINGKATKAN KEMAMPUAN MENULIS SISWA KELAS V SEKOLAH DASAR NEGERI 27 KOTA BENGKULU
}

\author{
Resnani \\ Universitas Bengkulu
}

\begin{abstract}
Abstrak
Tujuan penelitian ini adalah untuk meningkatkan aktivitas pembelajaran dan kemampuan menulis siswa dengan menggunakan teknik menulis semi terpimpin pada siswa kelas V SD Negeri 27 kota Bengkulu. Penelitian ini menggunakan metode Penelitian Tindakan Kelas (PTK) yang dilaksanakan secara kolaborasi antara peneliti, guru SD, dan mahasiswa (pratikan) S1 PGSD. Penelitian ini dilaksanakan di kelas V SD Negeri 27 kota Bengkulu sebanyak tiga siklus. Hasil penelitian menunjukkan bahwa (1) penggunaan teknik menulis semi terpimpin dapat meningkatkan aktivitas pembelajaran menulis pada siswa kelas V SD Negeri 27 kota Bengkulu karena teknik menulis semi terpimpin yang digunakan guru dapat membuat pembelajaran lebih bermakna bagi siswa dan dapat mengatasi kesulitan siswa dalam menulis, (2) penggunaan teknik menulis semi terpimpin dapat meningkatkan kemampuan menulis siswa kelas V SD Negeri 27 kota Bengkulu. Kemampuan menulis siswa meningkat karena guru menyediakan alat bantu menulis yang dapat mempermudah siswa dalam menuangkan ide, gagasan dalam tulisan.
\end{abstract}

Kata kunci: teknik menulis, semi terpimpin, kemampuan menulis

\section{PENDAHULUAN}

Salah satu keterampilan berbahasa yang mempunyai posisi yang sangat penting adalah menulis atau mengarang karena menulis merupakan salah satu kemampuan yang perlu dimiliki oleh siswa sekolah dasar (SD). Dengan memiliki kemampuan menulis, siswa dapat menyampaikan ide, gagasan, pengalamannya ke berbagai pihak. Di samping itu, siswa pun dapat meningkatkan dan memperluas pengetahuannya melalui tulisan-tulisan. Oleh karena, menulis merupakan keterampilan yang harus dikuasai oleh siswa termasuk siswa sekolah dasar (SD).

Menulis merupakan suatu kegiatan menyampaikan pesan dengan menggunakan tulisan sebagai medianya (Akhadiah dkk,
2008: 1.3). Selanjutnya, Suparno dan Yunus (2006: 1.24) mengemukakan bahwa menulis atau mengarang adalah penyampaian pesan (ide, gagasan, perasaan, atau informasi) secara tertulis kepada pihak lain (pembaca). Hal ini berarti, melalui menulis seseorang dapat mengekspresikan perasaan maupun pikirannya melalui bahasa tulisan.

Banyak hal yang dapat diperoleh dan dipetik dalam kegiatan menulis. Sehubungan dengan ini Suparno dan Yunus (2006 : 1.4) menyebutkan banyak manfaat yang dapat dipetik dari menulis. Manfaat tersebut antara lain: (1) menulis untuk meningkatkan kecerdasan, (2) menulis dapat mengembangkan daya inisiatif dan kreativitas, (3) menulis dapat menumbuhkan keberanian, dan (4) menulis dapat mendorong kemauan dan kemampuan mengumpulkan informasi. 
Keterampilan menulis yang dimiliki seseorang bukanlah datang secara otomatis sejak ia dilahirkan, melainkan harus melalui proses pembelajaran, praktik yang banyak, dan latihan secara teratur. Sehubungan dengan ini, Akhadiah dkk. (2008: 143) menyakatan bahwa "kemampuan menulis bukanlah kemampuan yang diwariskan secara turun temurun, tetapi merupakan hasil proses belajar-mengajar dan ketekunan berlatih."

Seseorang yang tekun berlatih, sering belajar, dan sering pratik menulis sekalipun, belum tentu memiliki keterampilan menulis yang handal. Ini artinya, menulis diperoleh dengan latihan intensif dan bimbingan yang sistematis. Karena menulis itu sulit, maka aktivitas menulis perlu mendapat perhatian dan bimbingan dari guru. Mengingat sangat pentingnya pembelajaran menulis di SD, maka guru harus betul-betul memahami aspek-aspek menulis di SD tersebut. Di samping itu, gurulah yang harus mampu memberi motivasi agar para siswa menyadari bahwa menulis merupakan salah satu keterampilan yang mutlak diperlukan untuk memperoleh keberhasilan dan kesuksesan dalam kehidupan.

Miskipun disadari bahwa penguasaan bahasa tulis mutlak diperlukan, dalam kenyataannya aktivitas menulis atau mengarang tidak banyak yang menyukainya dan kurang mendapat perhatian. Hal ini sejalan dengan pendapat Suparno dan Yunus (2006: 1.4) yang menyatakan bahwa dari survei yang pernah dilakukan terhadap guru bahasa Indonesia, umumnya responden menyatakan bahwa aspek pelajaran bahasa yang paling tidak disukai murid dan gurunya adalah menulis atau mengarang. Selain itu, Smith 1981 dalam Saddhono dan Slamet (2012: 102) menyatakan bahwa pengalaman belajar menulis atau mengarang yang dialami siswa di sekolah dasar tidak terlepas dari kondisi gurunya, dan teknik yang digunakan.

Pada hal, menurut Saddhono dan Slamet (2012: 95) keterampilan menulis merupakan salah satu bentuk keterampilan berbahasa yang sangat penting bagi para peserta didik baik selama mereka mengikuti pendidikan di berbagai jenjang maupun dalam kehidupan nanti di masyarakat. Oleh sebab itu, agar pembelajaran menulis lebih baik dan efektif dapat dilakukan oleh siswa, maka guru sebaiknya menggunakan teknik yang sesuai dengan karakteristik dan perkembangan kognitif anak usia SD.

Dengan kedudukannya yang sangat penting tersebut, maka pembelajaran menulis mempunyai porsi yang lebih banyak pada setiap kurikulum di berbagai sekolah, termasuk sekolah dasar. Di dalam Kurikulum Tingkat Satuan Pendidikan (KTSP) 2006, dijelaskan bahwa materi pembelajaran menulis (mengarang) di kelas $\mathrm{V}$ SD memiliki porsi yang paling banyak dibandingkan dengan tiga keterampilan yang lain (menyimak, berbicara, dan membaca). Ada enam Kompetensi Dasar terkait dengan menulis. Salah satu di antaranya adalah Kompetensi 4.1 yaitu menulis berbagai karangan dengan memperhatikan pilihan kata dan penggunaan ejaan (Depdiknas 2007). Hal ini memberi indikasi bahwa kemampuan menulis merupakan hal sangat penting bagi keberhasilan siswa dalam studinya.

Berdasarkan hasil pengamatan dan wawancara dengan guru kelas di SD Negeri 27 Kota Bengkulu, kenyataan di lapangan menunjukkan bahwa menulis seringkali dirasakan sebagai suatu beban yang berat dan menjadi hal yang menakutkan bagi siswa. Hal ini disebabkan kurangnya pemahaman dan kemampuan siswa terhadap pembelajaran menulis. Selain itu, peneliti juga mengadakan pengamatan langsung pada saat guru atau mahasiswa PPL 2 (praktikan) 
melaksanakan proses pembelajaran bahasa Indonesia pada materi menulis portofolio. Pada akhir pembelajaran guru mengadakan evaluasi (post tes). Kenyataan menunjukkan bahwa nilai rata-rata yang diperoleh adalah 5,7 (23,5\%). Nilai tersebut belum mencapai standar ketutasan belajar klasikal maupun standar KKM yang ditentukan oleh sekolah yang bersangkutan.

Rendahnya nilai yang diperoleh siswa disebabkan beberapa hal, antara lain; (a) teknik yang digunakan dalam pembelajaran menulis masih monoton; (b) guru/praktikan tidak menggali pengalaman siswa, tidak membimbing siswa yang mengalami kesulitan; (c) guru/praktikan kurang memperhatikan karakteristik dan perkembangan mental siswa sekolah dasar yang masih memerlukan bimbingan dalam belajar, (d) guru/praktikan tidak memberikan contoh mengarang (menulis) terlebih dahulu. Dalam hal ini siswa disuruh mengarang secara bebas sesuai dengan keinginannya; (e) guru tidak interaksi antara guru/praktikan dengan siswa belum optimal. Pernyataan tersebut, diperkuat dengan pendapat Abidin (2013: 190) yang menyatakan bahwa rendahnya kemampuan siswa dalam menulis disebabkan oleh berbagai faktor, di antaranya rendahnya peran guru dalam membina atau membimbing siswa agar terampil menulis, kurangnya sentuhan guru dalam hal memberikan teknik dan strategi menulis yang tepat, membina siswa untuk berlatih mengemukakan gagasan masih belum optimal.

\section{Berdasarkan}

masalah-masalah tersebut, maka untuk meningkatkan kualitas pembelajaran menulis di SD dilakukan kolaborasi antara dosen PGSD, guru SD, kepala sekolah dan mahasiswa/pratikan PGSD PPL-2 untuk melakukan perbaikan pembelajaran menulis pada mata pelajaran bahasa Indonesia. Sebagai alternatif pemecahan masalah dilakukan tindakan kelas dengan menggunakan teknik pembelajaran yang dapat menumbuhkan motivasi dan keinginan serta dapat menarik perhatian siswa dalam pembelajaran.

Salah satu tenik yang dapat digunakan adalah teknik menulis semi terpimpin. Teknik ini merupakan teknik yang dapat dilakukan guru dalam upaya membantu siswa agar mereka mudah menuangkan ide atau gagasan ke dalam tulisan. Sehubungan dengan ini Subiyakto, 1993 dalam Haryanto (2001: 10) mengemukakan bahwa menulis semi terpimpin berarti aktivitas menulis sebagian dikuasai atau dibantu oleh guru. Ini dimaksudkan untuk membantu kesulitan siswa di dalam menulis. Selanjutnya, Saddhono dan Salamet (2012: 103) mengungkapkan bahwa menulis terpimpin dapat dilakukan dengan bantuan gambar dan kerangka karangan, penyusunan paragraf berdasarkan kalimat-kalimat.

Teknik menulis semi terpimpin dalam penelitian ini adalah teknik menulis dengan disediakannya panduan atau gatragatra agar siswa lebih mudah menuangkan ide atau gagasannya ke dalam karangan. Alat bantu yang dapat digunakan antara lain: menyediakan ide pokok atau kalimat utama pada setiap paragraf yang akan dikembangkan, menyediakan kalimat yang di acak pada setiap paragraf, dan mengarang berdasarkan gambar seri. Sedangkan bahan atau alat bantu pembelajaran disesuaikan dengan bahan yang ada dalam kurikulum dan buku paket bahasa Indonesia kelas V Sekolah Dasar.

Berdasarkan latar belakang dan permasalahan di atas, maka tujuan penelitian ini adalah untuk meningkatkan aktivitas pembelajaran menulis dengan menggunakan teknik menulis semi terpimpin pada siswa kelas V SD Negeri 27 kota Bengkulu, dan 
untuk meningkatkan kemampuan menulis dengan penggunaan teknik menulis semi terpimpin pada siswa kelas V SD Negeri 27 kota Bengkulu.

\section{METODE}

Penelitian ini sebagai langkah untuk memperbaiki pembelajaran bahasa Indonesia pada materi keterampilan menulis atau mengarang di SD Negeri 27 kota Bengkulu dalam upaya meningkatkan aktivitas pembelajaran dan kemampuan menulis siswa. Metode yang digunakan adalah Penelitian Tindakan Kelas (Classroom Action Research) berkolaborasi dengan model guru (mahasiswa PPL-2) sebagai pratikan. Subjek penelitian ini adalah siswa kelas V SD Negeri 27 kota Bengkulu.

Prosedur penelitian yang digunakan berupa proses pengkajian berdaur. Wardani (2007: 2.4) menyatakan bahwa ada empat tahap penting dalam penelitian tindakan kelas yaitu: tahap prencanaan (planning), pelaksanaan (action), pengamatan (observation), dan refleksi (reflection). Instrumen yang digunakan adalah lembar observasi guru dan siswa dan lembar tes kemampuan menulis siswa. Lembar pengamatan digunakan pada saat proses pembelajaran, dan lembar tes digunakan pada akhir pembelajaran. Teknik analisis data yang digunakan adalah pengamatan, dan tes kemampuan menulis. Data hasil observasi guru dan siswa dihitung dengan menggunakan rata-rata skor dengan kategori baik, cukup, dan sedang. Sedangkan hasil tes dianalisis dengan mencari nilai rata-rata dengan persentase ketuntasan belajar secara klasikal.

\section{HASIL DAN PEMBAHASAN}

Penelitian tindakan kelas ini dilaksanakan di SD Negeri 27 kota Bengkulu sebanyak tiga siklus. Data yang dikumpulkan dalam penelitian ini adalah data hasil observasi dan hasil tes kemampuan menulis siswa. Hasil penelitian yang dideskripsikan sesuai dengan masalah atau tujuan dalam penelitian dan siklus yang dilaksanakan. Adapun hasil penelitian pada setiap siklus diuraikan seperti berikut ini.

\section{Hasil Penelitian Siklus Pertama}

Pelaksanaan tindakan perbaikan pada siklus pertama membahas tentang karangan dengan disediakan gambar seri yang berisi judul dan ide/kalimat pokok, selanjutnya, siswa diminta mengembangkan ide pokok tersebut ke dalam ide penjelas. Kegiatan pembelajaran berlangsung sesuai dengan perencanaan. Hasil analisis data menunjukkan bahwa skor rata-rata aktivitas guru adalah sebesar 20,5 dengan kategori cukup. Skor rata-rata aktivitas siswa adalah sebesar 21,5 dengan kategori cukup.

Hasil refleksi menunjukkan bahwa terdapat keunggulan-keunggulan dan kelemahan-kelemahan dalam penggunaan teknik menulis semi terpimpin dalam pembelajaran menulis pada mata pelajaran bahasa Indonesia. Keunggulan tesebut adalah (1) penggunaan teknik menulis semi terpimpin dapat menimbulkan motivasi atau minat siswa untuk menulis, (2) siswa senang menulis dengan bantuan guru, (3) interaksi antara guru dengan siswa cukup baik. Kelemahannya adalah (1) masih banyak karangan siswa yang tidak mengikuti atauran dalam menulis, (2) siswa masih kesulitan dalam mengembangkan ide pokok ke dalam ide penjelas, (3) sebagian siswa tidak menyelesaikan tulisan, (4) siswa kurang 
kreatif, dan hasil evaluasi masih rendah yaitu 6,12 dengan persentase ketuntasan 71,8\%. Berdasarkan temuan tersebut, maka dilakukan siklus berikutnya untuk melakukan perbaikan-perbaikan.

\section{Hasil Penelitian Siklus Kedua}

Pelaksanaan tindakan pada siklus kedua membahas materi menulis prosa deskriptif dengan alat bantu yang disediakan adalah menyusun kalimat acak menjadi paragraf yang padu. Kegiatan pembelajaran berlangsung sesuai dengan perencanaan. Hasil analisis data menunjukkan bahwa ada peningkatan baik aktivitas pembelajaran maupun kemampuan menulis siswa walaupun masih berada pada kategori cukup. Hasil tersebut yaitu skor rata-rata aktivitas guru sebesar 24,5 dengan kategori cukup dan skor rata aktivitas siswa sebesar 26,5 dengan kategori cukup.

Hasil refleksi siklus kedua menunjukkan beberapa keunggulan dan kelemahan. Keunggulannya adalah (1) penerapan menulis dengan teknik semi terpimpin mendorong siswa lebih bersemangat mengerjakan tugas, (2) siswa sudah mulai berani bertanya, (3) guru bertindak sebagai fasilitator. Kelemahannya adalah (1) ada beberapa siswa tidak terlibat secara aktif, (2) beberapa siswa masih perlu mendapat bimbingan khusus, (3) prestasi belajar siswa dalam bentuk karangan masih di bawah indikator keberhasilan yaitu nilai rata-rata 6,92 dengan persentase ketuntasan 75,23\%. Hal ini menunjukkan bahwa kemampuan menulis siswa belum mencapai hasil yang diharapkan, maka perlu dilakukan tindakan perbaikan pada siklus berikutnya.

\section{Hasil Penelitian Siklus Ketiga}

Pada siklus ketiga, tindakan yang dilakukan adalah membahas materi mengarang dengan menyediakan alat bantu menulis yang disediakan guru adalah menyediakan wacana rumpang pada awal, tengah dan akhir paragraf. Dalam hal ini, siswa diminta untuk melengkapi kalimat rumpang dengan memilih jawan alternatif yang disediakan oleh guru. Kegiatan pembelajaran berlangsung sesuai dengan perencanaan. Hasil analisis data menunjukkan bahwa ada peningkatan baik aktivitas pembelajaran maupun kemampuan menulis siswa. Hasil tersebut yaitu skor ratarata aktivitas guru sebesar 32,5 dengan kategori baik dan skor rata aktivitas siswa sebesar 31,5 dengan kategori baik.

Hasil refleksi siklus ketiga menunjukkan beberapa keunggulan dan kelemahan. Keunggulannya adalah (1) pembelajaran lebih bermakna, (2) kemampuan menulis siswa sudah mengikuti aturan dalam penulisan, (4) interaksi antara siswa dengan guru tercipta lebih kondusif, (3) kemampuan menulis atau mengarang siswa sudah sesuai dengan yang diharapkan dalam KKM SD yang bersangkutan yaitu rata nilai adalah secara klasikal adalah 7,6 dengan persentase ketuntasan $86,62 \%$. Kelemahannya adalah masih ada siswa yang perlu mendapat bimbingan khusus.

Berdasarkan uraian di atas, penggunaan teknik menulis semi terpimpin dalam pembelajaran menulis dapat meningkatkan aktivitas pembelajaran maupun hasil belajar siswa berupa kemampuan siswa dalam menulis. Hasil tersebut ditunjukkan nilai aktivitas pembelajaran dan kemampuan menulis siswa meningkat pada setiap siklus. Aktivitas pembelajaran pada siklus I sebesar 20,5 dengan kategori cukup meningkat menjadi 24,5 dengan kategori cukup, selanjutnya meningkat lagi pada siklus ketiga sebesar 32,5 dengan kategori baik. Demikian juga untuk aktivitas siswa siklus pertama sebesar 
21,5 dengan kategori cukup meningkat pada siklus kedua sebesar 26,6 masih dalam kategori cukup meningkat pada siklus ketiga sebesar 31,5 dengan ketegori baik.

Kemampuan siswa dalam menulis juga meningkat setiap siklus. Siklus pertama ratarata nilai kemampuan siswa dalam menulis dengan menggunakan teknik menulis terpimpin 6,12 dengan persentase ketuntasan secara klasikal adalah $71,85 \%$, meningkat pada siklus kedua sebesar 6,92 dengan ketuntasan belajar secara klasikal sebesar 75,23, meningkat lagi pada siklus ketiga sebesar 7,6 dengan persentase ketuntasan $86,62 \%$. Hasil tesebut menunjukkan bahwa pembelajaran menulis lebih bermakna apabila guru menciptakan situasi pembelajaran dengan membantu atau membimbing siswa secara langsung dengan menyediakan berbagai alat bantu dalam menulis. Alat bantu tersebut berupa gambar seri, ide/kalimat utama untuk dikembangkan ke dalam kalimat penjelas, kalimat yang di acak, atau kalimat rumpang.

Pernyataan ini sesuai dengan pendapat Slamet (2012: 103 yang menyatakan bahwa alat bantu menulis terpimpin dapat dilakukan dengan bantuan gambar, kerangka karangan, penyusunan kalimat. Penyajian alat bantu tersebut mampu menimbulkan atau mendorong minat siswa untuk menulis, siswa lebih percaya diri sehingga siswa lebih termotivasi untuk mengekspresikan ide maupun pendapatnya ke dalam sebuah tulisan. Hal ini tentu tidak terlepas dari peran guru sebagai pembimbing dalam pembelajaran.

Sehubungan dengan ini Saddhono dan Slamet (2012: 102) menyatakan bahwa pengalaman belajar menulis atau mengarang yang dialami siswa di sekolah dasar tidak terlepas dari kondisi gurunya, dan teknik yang digunakan. Pembelajaran menulis seperti ini merupakan tahap awal untuk membekali siswa agar terampil menulis ketika siswa diberi kesempatan untuk mengarang bebas sebagai tahap akhir pengajaran mengarang yang diberikan kepada siswa. Dengan demikian, guru pun tidak terlalu sulit melakukan evaluasi. Selain itu, penggunaan teknik menulis semi terpimpin ini sangat sesuai dengan karakteristik dan perkembangan mental siswa sekolah dasar yang tentunya masih banyak memerlukan bimbingan dari guru.

\section{SIMPULAN}

Berdasarkan hasil penelitian dan pembahasan dapat disimpulkan seperti berikut ini.

1. Penggunaan teknik menulis semi terpimpin dapat meningkatkan aktivitas pembelajaran menulis pada siswa kelas V SD Negeri 27 kota Bengkulu. Teknik menulis semi terpimpin yang digunakan guru dapat membuat pembelajaran lebih bermakna bagi siswa dan dapat mengatasi kesulitan siswa dalam menulis.

2. Penggunaan teknik menulis semi terpimpin dapat meningkatkan kemampuan menulis siswa kelas V SD Negeri 27 kota Bengkulu.Kemampuan menulis siswa meningkat karena guru menyediakan alat bantu menulis yang dapat mempermudah siswa dalam menuangkan ide, gagasan dalam tulisan.

\section{SARAN}

Berdasarkan hasil penelitian tindakan kelas ini, maka disampaikan saran sebagai berikut ini.

1. Disarankan kepada guru SD Negeri 27 kota Bengkulu untuk dapat mensoialisasikan teknik menulis semi 
terpimpin dalam pembelajaran bahasa Indonesia khususnya tentang materi menulis karena teknik ini mampu menciptakan suasana belajar yang kondusif, efektik dan bermakna serta dapat mengatasi kesulitan siswa dalam menulis.

2. Kepada Mahasiswa S-1 PGSD sebagai pratikan yang melakukan PPL 2 agar dapat ikut serta mensosialisasikan pemebelajaran menulis dengan menggunakan teknik menulis semi terpimpin.

\section{DAFTAR PUSTAKA}

Akhadiah Sabarti,Arsjad G. Ridwan 2008. Pembinaan Kemampuan Menulis Bahasa Indonesia. Jakarta: Erlangga
Abidin, Yunus, 2013. Pembelajaran Bahasa Berbasis Pendidikan Karakter. Bandung: Refika Aditama.

Depdiknas 2007. Kurikulum Tingkat Satuan Pendidikan (KTSP) 2006. Jakarta

Saddhono, Kundharu, Slamet, ST. Y., 2012. Meningkatkan Keterampilan Berbahasa Indonesia (Teori dan Aplikasi). Bandung: Karya Putra Darwati.

Suparno, Yunus, Ahmad, 2006. Keterampilan Dasar Menulis.Jakarta: Universitas terbuka.

Wardhani, dkk. (2007). Penelitian Tindakan Kelas. Jakarta: Universitas Terbuka. 